University of Nebraska - Lincoln

DigitalCommons@University of Nebraska - Lincoln

2000

\title{
Yields and Nitrogen Dynamics in a Rice-Wheat System Using Green Manure and Inorganic Fertilizer
}

Milkha S. Aulakh

Punjab Agricultural University

Tejinder S. Khera

Punjab Agricultural University

John W. Doran

University of Nebraska-Lincoln, jdoran1@unl.edu

Kuldip Singh

Punjab Agricultural University

Bijay Singh

Punjab Agricultural University

Follow this and additional works at: https://digitalcommons.unl.edu/usdaarsfacpub

Part of the Agricultural Science Commons

Aulakh, Milkha S.; Khera, Tejinder S.; Doran, John W.; Singh, Kuldip; and Singh, Bijay, "Yields and Nitrogen Dynamics in a Rice-Wheat System Using Green Manure and Inorganic Fertilizer" (2000). Publications from USDA-ARS / UNL Faculty. 303.

https://digitalcommons.unl.edu/usdaarsfacpub/303

This Article is brought to you for free and open access by the U.S. Department of Agriculture: Agricultural Research Service, Lincoln, Nebraska at DigitalCommons@University of Nebraska - Lincoln. It has been accepted for inclusion in Publications from USDA-ARS / UNL Faculty by an authorized administrator of DigitalCommons@University of Nebraska - Lincoln. 


\title{
Yields and Nitrogen Dynamics in a Rice-Wheat System Using Green Manure and Inorganic Fertilizer
}

\author{
Milkha S. Aulakh,* Tejinder S. Khera, John W. Doran, Kuldip-Singh, and Bijay-Singh
}

\begin{abstract}
Integrating fertilizer N (FN) with legume green manures (GM) can foster sustainable and environmentally sound agricultural systems in subtropical, semiarid soils low in organic matter. A 4-yr replicated field experiment with irrigated rice (Oryza sativa $\mathrm{L}$.) and wheat (Triticum aestivum $\mathbf{L}$.) rotations was conducted on a sandy loam soil in the Punjab of India to evaluate the effects of incorporating cowpea (Vigna unguiculata L.) or sesbania (Sesbania aculeata L.) GM on crop productivity, $\mathrm{N}$-use efficiency, and $\mathrm{NO}_{3}$ leaching. Rice grain yields with pretransplant incorporation of 20 and $40 \mathrm{Mg} \mathrm{GM} \mathrm{ha}^{-1}$ $\left(G_{20}\right.$ and $\left.G_{40}\right)$ ranged from 5.18 to $5.81 \mathrm{Mg} \mathrm{ha}^{-1}$, which were equivalent to the $5.40 \mathrm{Mg} \mathrm{ha}^{-1}$ obtained with $120 \mathrm{~kg} \mathrm{FN} \mathrm{ha}^{-1}\left(\mathrm{FN}_{120}\right)$. Rice yield with $60 \mathrm{~kg} \mathrm{FN} \mathrm{ha}^{-1}\left(\mathrm{FN}_{60}\right)$ and $\mathrm{GM}_{20}$ was double the control yield and $6 \%$ greater than the $\mathbf{F N}_{120}$ treatment. Nitrogen utilization by rice was greater for $\mathbf{G M}_{20}$ than $\mathbf{F N}$, as indicated by greater fertilizer $N$ equivalents and an apparent $N$ recovery by rice of 79 vs. $63 \%$. While FN had no residual effects, residual GM produced greater wheat yields, indicating that $\mathrm{FN}$ applied to wheat could be reduced by $25 \%$. Soil $\mathrm{NO}_{3}-\mathrm{N}$ leaching to $60 \mathrm{~cm}$ in the rice crop was apparently used by the subsequent wheat crop, which has a deeper and more extensive rooting system. After $4 \mathrm{yr}$, use of $\mathrm{FN}_{120}$ for both crops resulted in $35 \mathrm{~kg}$ of residual $\mathrm{NO}_{3}-\mathrm{N} \mathrm{ha}^{-1}$ in the $150-\mathrm{cm}$ soil profile ( $74 \%$ below $90 \mathrm{~cm}$ ), whereas only $19 \mathrm{~kg} \mathrm{NO}_{3}-\mathrm{N} \mathrm{ha}^{-1}$ remained with $\mathbf{G M}_{20}$ plus $\mathbf{F N}_{60}$. Use of $\mathbf{G M}_{20}$ with $\mathbf{F N}_{60}$ for a rice-wheat rotation demonstrated greater yields of rice and wheat, 25 to $50 \%$ reduction in fertilizer $\mathrm{N}$ use, and decreased potential for groundwater $\mathrm{NO}_{3}$ contamination.
\end{abstract}

$\mathrm{W}$ HILE ONLY ONE-HALF of the 146 million ha under rice cultivation in the world is irrigated, it represents $\approx 75 \%$ of total rice production (IRRI, 1991). In Asia, irrigated rice is often a part of annual double cropping systems where upland crops such as wheat, maize (Zea mays L.), vegetables, or legumes follow rice, with rice-wheat as the major cropping system. Production of rice and wheat has responded to $\mathrm{N}$ rates up to $120 \mathrm{~kg} \mathrm{~N} \mathrm{ha}{ }^{-1}$ on these subtropical, semiarid soils (Maskina et al., 1988), which are inherently low in organic matter and $\mathrm{N}$ levels.

In recent years, fertilizer cost and concern for sustainable soil productivity and ecological stability in relation to chemical fertilizer use have emerged as important issues (Aulakh and Pasricha, 1997a; Aulakh and BijaySingh, 1997). There is a renewed interest in organic manures, such as farmyard manures, composts, and green manures, as sources of plant nutrients (Yadvinder-Singh et al., 1988; Aulakh, 1994). Farmyard ma-

M.S. Aulakh, T.S. Khera, and Bijay-Singh, Dep. of Soils, Punjab Agricultural Univ., Ludhiana 141004, Punjab, India; J.W. Doran, USDA-ARS, East Campus, Univ. of Nebraska, Lincoln, NE 68583; and Kuldip-Singh, Farm Advisory Service, Punjab Agricultural University, Kapurthala, Punjab, India. Received 29 Apr. 1998. *Corresponding author (jdoran1@unl.edu).

Published in Soil Sci. Soc. Am. J. 64:1867-1876 (2000). nures and composts are in limited supply and may have low and variable nutrient contents. The more readily available green manures constitute a valuable source of both $\mathrm{N}$ and organic matter (Buresh and De Datta, 1991; Ladha and Garrity, 1994; Ladha et al., 1996; Bijay-Singh and Yadvinder-Singh, 1997; Aulakh and Pasricha, 1997b).

In a rice-wheat system, green manure crops such as cowpea and sesbania can be grown for 45 to $60 \mathrm{~d}$ in May and June when fields are fallow after the harvest of wheat. The green plants are incorporated into the soil in the third or fourth week of June prior to the transplanting of rice. Rice is grown during the monsoon season from July to October and wheat in winter from November to April. Information on benefits of integrating $\mathrm{FN}$ with legume GM or its use as an alternative source of nutrients will contribute greatly to development of sustainable agricultural management systems in semiarid, subtropical regions.

Nitrogen movement below the root zone and into the groundwater (Olson et al., 1970; Spalding and Kitchen, 1988) can cause human and animal health problems (USEPA, 1985). Leaching losses of $\mathrm{N}$ mainly occur as $\mathrm{NO}_{3}$, while leaching of $\mathrm{NH}_{4}$ is only a problem when applied in very large quantities on coarse-textured soils. Recent reviews (Aulakh, 1994; Bijay-Singh et al., 1995; Aulakh and Bijay-Singh, 1997) have revealed few studies on $\mathrm{NO}_{3}$ leaching in intensively cultivated semiarid, subtropical or tropical soils and no reports have addressed rice - wheat cropping systems. In most of these studies, the distribution of $\mathrm{NO}_{3}$ in the soil profile has been determined at the end of different field experiments. No studies are available that report changes in $\mathrm{NO}_{3}$ and $\mathrm{NH}_{4}$, during and after the harvest of each crop grown in a rotation, occurring under dry and flooded cycles, application of FN, and the incorporation of GM or crop residues.

Traditional flooded paddy soils are fine textured with very low percolation rates. Upon flooding, these soils become anaerobic and nitrification is severely reduced, resulting in the continuous accumulation of $\mathrm{NH}_{4}-\mathrm{N}$. However, with increasing food and fiber demands to support growing populations as well as the creation of additional canal and tubewell water irrigation facilities, coarse-textured highly porous soils of subtropical regions are now used for raising both upland crops as well as wetland rice (Aulakh and Bijay-Singh, 1997; Aulakh and Pasricha, 1997b). In porous soils under rice, continu-

\footnotetext{
Abbreviations: ANR, apparent $\mathrm{N}$ recovery; $D_{\mathrm{b}}$, bulk density; FN, fertilizer $\mathrm{N} ; \mathrm{FN}_{0}, \mathrm{FN}_{60}, \mathrm{FN}_{90}$, and $\mathrm{FN}_{120}$ represent $0,60,90$, and $120 \mathrm{~kg}$ fertilizer $\mathrm{N} \mathrm{ha}^{-1}$, respectively; FNE, fertilizer $\mathrm{N}$ equivalent; GM, legume green manure; $\mathrm{GM}_{0}, \mathrm{GM}_{20}$, and $\mathrm{GM}_{40}$ represent 0,20 , and $40 \mathrm{Mg}$ fresh weight green manure $\mathrm{ha}^{-1}$, respectively; HI, harvest index; OC organic $\mathrm{C}$; RCBD, randomized complete block design.
} 
Table 1. Characteristics of Tolewal sandy loam soil (Typic Ustochrept).

\begin{tabular}{|c|c|c|c|c|c|c|c|}
\hline Soil depth & Sand & Silt & Clay & Organic C & $\mathrm{CaCO}_{3}$ equivalent & pH & $E C \dagger(1: 2)$ \\
\hline $\mathbf{c m}$ & $\longrightarrow$ & 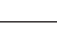 & _ & 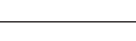 & 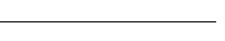 & & $d S m^{-1}$ \\
\hline 0-15 & 710 & 150 & 140 & 3.8 & 3 & 7.9 & 0.21 \\
\hline 15-30 & 790 & 100 & 110 & 1.9 & 5 & 7.9 & 0.16 \\
\hline $30-60$ & 830 & 70 & 100 & 1.4 & 6 & 7.8 & 0.10 \\
\hline $60-90$ & 810 & 60 & 130 & 1.2 & 8 & 7.9 & 0.10 \\
\hline $90-120$ & 800 & 50 & 150 & 1.0 & 10 & 8.0 & 0.12 \\
\hline $120-150$ & 770 & 50 & 180 & 0.6 & 12 & 8.1 & 0.14 \\
\hline
\end{tabular}

$\dagger \mathbf{E C}=$ electrical conductivity.

ous flooding cannot be maintained due to high water percolation rates. Thus the porous soils exhibit alternate aerobic and anaerobic conditions and can support nitrification (Aulakh et al., 1996). Nitrate enrichment of groundwater beneath several irrigated porous soils is evident from the $\mathrm{NO}_{3}$ analysis of tubewell waters (Bajwa et al., 1993); however, no data have been reported on the effects of $\mathrm{N}$ fertilization and green manure crops on the dynamics of $\mathrm{NO}_{3}$ and $\mathrm{NH}_{4}$ in porous irrigated soils. Such studies would become more important as porous soils are increasingly used for irrigated ricewheat cropping systems.

A 4-yr field study with an irrigated rice-wheat cropping system in a subtropical, semiarid porous soil was undertaken to investigate (i) the individual and combined effects of GM and FN on the yield response and $\mathrm{N}$-use efficiency of irrigated rice, (ii) the capacity of GM to substitute for FN and its residual effect on the succeeding wheat crop, and (iii) $\mathrm{N}$ dynamics in soil during and after the harvest of rice and wheat crops, including the mineralization of GM-N and the amounts of $\mathrm{NO}_{3}-\mathrm{N}$ and $\mathrm{NH}_{4}-\mathrm{N}$ in the soil profile and the potential for their leaching below the rooting zone.

\section{MATERIALS AND METHODS}

A 4-yr field experiment was conducted during 1992 to 1996 on a semiarid irrigated Tolewal sandy loam (Typic Ustochrept) soil at Punjab Agricultural University Research Farm, Ludhiana, India. Ludhiana is located $30^{\circ} 54^{\prime} \mathrm{N}$ and $75^{\circ} 48^{\prime} \mathrm{E}$ and is $247 \mathrm{~m}$ above mean sea level. The mean monthly minimum air temperatures during the $4 \mathrm{yr}$ of the study ranged

Table 2. Treatment combinations and rates of fertilizer $\mathbf{N}(\mathbf{F N})$ and green manure (GM) applications.

\begin{tabular}{|c|c|c|c|c|}
\hline \multirow{2}{*}{\multicolumn{2}{|c|}{ Treatment description $\dagger$}} & \multicolumn{3}{|c|}{ Amount added } \\
\hline & & \multicolumn{2}{|c|}{ Rice } & \multirow{2}{*}{$\frac{\text { Whea }}{\text { FN }}$} \\
\hline Rice & Wheat & GM & FN & \\
\hline & & $\mathrm{Mg} \mathrm{ha}^{-1}$ & 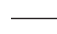 & -1 \\
\hline $\mathbf{G M}_{0} \mathbf{F N _ { 0 }}$ & $\mathbf{F N}_{0}$ & $\mathbf{0}$ & $\mathbf{0}$ & $\mathbf{0}$ \\
\hline $\mathbf{G M}_{0} \mathbf{F N}_{60}$ & $\mathbf{F N}_{60} \div \S$ & 0 & 60 & 60 \\
\hline $\mathbf{G M}_{0} \mathbf{F N}_{120}$ & $\mathbf{F N}_{90}$ & $\mathbf{0}$ & 120 & 90 \\
\hline $\mathbf{G M}_{0} \mathbf{F N}_{120}$ & $\mathbf{F N}_{120}$ & $\mathbf{0}$ & 120 & 120 \\
\hline $\mathbf{G M}_{20} \mathbf{F N}_{0}$ & $\mathbf{F N}_{0}$ & 209 & $\mathbf{0}$ & 0 \\
\hline $\mathbf{G M}_{20} \mathbf{F N}_{60}$ & $\mathbf{F N}_{90}$ & 20 & 60 & 90 \\
\hline $\mathbf{G M}_{20} \mathbf{F N}_{120}$ & $\mathbf{F N}_{90}$ & 20 & 120 & 90 \\
\hline $\mathbf{G M}_{40} \mathbf{F N}_{0}$ & $\mathbf{F N}_{0}+$ & 409 & 0 & 0 \\
\hline $\mathbf{G M}_{40} \mathbf{F N}_{60}$ & $\mathbf{F N}_{90}$ & 40 & 60 & 90 \\
\hline $\mathbf{G M}_{40} \mathbf{F N}_{120}$ & $\mathbf{F N}_{90} \div$ & 40 & 120 & 90 \\
\hline
\end{tabular}

$\dagger$ GM is green manure and FN is fertilizer $\mathbf{N}$; subscripts denote application rates $\left(\mathrm{Mg} \mathrm{ha}^{-1}\right.$ and $\mathrm{kg} \mathrm{ha}^{-1}$, respectively).

+ Treatment was not included in Year 1.

$\$$ Treatment was not included in Year 2.

If In Year 1, 25 and $50 \mathrm{Mg} \mathrm{ha}^{-1}$ green manure was added instead of 20 and $40 \mathrm{Mg} \mathrm{ha}^{-1}$. from 5 to $8^{\circ}$ in January to 26 to $27^{\circ} \mathrm{C}$ in June, while maximum temperatures ranged from 8 to $19^{\circ} \mathrm{C}$ in January to 35 to $40^{\circ} \mathrm{C}$ in June. The annual rainfall ranged from 593 to $1227 \mathrm{~mm}$, with 74 to $85 \%$ occurring from July to September. Characteristics of the Tolewal sandy loam soil (Table 1) were determined by standard methods (Westerman, 1990). The plow layer $(0-15 \mathrm{~cm})$ had total $\mathrm{N}$ content of $0.4 \mathrm{~g} \mathrm{~kg}^{-1}$. The infiltration rate of the unpuddled soil averaged $1.0 \mathrm{~cm} \mathrm{~h}^{-1}$, and the puddled soil rate was $0.2 \mathrm{~cm} \mathrm{~h}^{-1}$. The groundwater table was below $8 \mathrm{~m}$.

Treatments for wetland rice included three levels of FN $(0$, 60 , and $\left.120 \mathrm{~kg} \mathrm{~N} \mathrm{ha}^{-1}\right)$ and three levels of GM (0, 20, and $40 \mathrm{Mg}$ fresh biomass $\mathrm{ha}^{-1}$ ) that were arranged in a randomized complete block design (RCBD) with three replications. Total numbers of treatment combinations were seven in Year 1, nine in Year 2, and 10 in Years 3 and 4 (Table 2). In Year 1, GM rates of 25 and $50 \mathrm{Mg} \mathrm{ha}^{-1}$ were incorporated instead of 20 and $40 \mathrm{Mg} \mathrm{ha}^{-1}$. For the sake of simplicity, these are referred to as 20 and $40 \mathrm{Mg} \mathrm{GM} \mathrm{ha}^{-1}$ throughout the text.

Cowpea in Year 1 and sesbania in the following $3 \mathrm{yr}$ were seeded as green manure crops in the fourth week of April or first week of May in GM plots. After irrigation, cowpea or sesbania seed was drilled in rows $20 \mathrm{~cm}$ apart at the rate of $50 \mathrm{~kg} \mathrm{ha}^{-1}$ in near field capacity soil moisture. After 50 to $53 \mathrm{~d}$, the GM crop was harvested and an appropriate amount of fresh biomass of GM (20 or $40 \mathrm{Mg} \mathrm{ha}^{-1}$ ) was uniformly distributed in respective treatment plots and incorporated into the soil in June, $2 \mathrm{~d}$ before transplanting rice plants.

Rice (cv. PR 106) was seeded in a separate field adjoining the experimental plots in the second week of May and fertilized with $15 \mathrm{~kg} \mathrm{~N} \mathrm{ha}^{-1}$ and $17.5 \mathrm{~kg} \mathrm{P} \mathrm{ha}^{-1}$ as diammonium phosphate, and $10 \mathrm{~kg}$ zinc sulfate ha ${ }^{-1}$. Two weeks later, $25 \mathrm{~kg}$ $\mathrm{N} \mathrm{ha}^{-1}$ as urea was top-dressed prior to irrigation. Healthy 45-d-old plants were transplanted two plants per hill in the third or fourth week of June. Rows were $20 \mathrm{~cm}$ apart with an in-row spacing of $15 \mathrm{~cm}$, and the individual plots measured 3 by $10 \mathrm{~m}$. Fertilizer $\mathrm{N}$ as urea was applied in three equal amounts at $\approx 0,3$, and $6 \mathrm{wk}$ after transplanting. The experimental area was bordered with 10 rows of nonexperimental rice plants on all sides of the field. The crop was irrigated on a daily basis during the first month and thereafter on an as-needed basis at intervals to prevent a dry spell (soil surface without overlying water) of more than $2 \mathrm{~d}$. This is a recommended practice of intermittent submergence for rice as it saves water but does not reduce rice yields (Sandhu et al., 1980). Irrigation water was used either from canal or tubewell and contained nominal $\mathrm{N}\left(<0.5 \mathrm{mg} \mathrm{L}^{-1}\right)$. At maturity, the rice crop was harvested in the first or second week of October. Grain and straw yields were recorded and grain data are expressed on the basis of $140 \mathrm{~g}$ water $\mathrm{kg}^{-1}$ dry matter $(14 \%)$.

Wheat (cv. HD 2329) was drilled at $40 \mathrm{~kg}$ seed ha ${ }^{-1}$ in early November in the same permanent plots as rice in rows $20 \mathrm{~cm}$ apart. A uniform application of $26.2 \mathrm{~kg} \mathrm{P} \mathrm{ha}^{-1}$ as single superphosphate was drilled in all plots at the time of seeding. Four rates of $\mathrm{FN}\left(0,60,90\right.$, or $\left.120 \mathrm{~kg} \mathrm{~N}^{-1}\right)$ as urea were broadcast in two equal splits, at seeding and 4 to 5 wk later $(1 \mathrm{~d}$ after first irrigation). Thereafter irrigation was applied when required 
to maintain adequate moisture conditions $(>50 \%$ of plantavailable soil water). The middle $15 \mathrm{~m}^{2}$ of each plot was harvested in the second or third week of April. Grain and straw yields were recorded and the data are expressed on a dry weight basis. Aboveground crop residues except stubbles of both crops were removed from the plots. Concentration of $\mathrm{N}$ in grain and straw samples of both rice and wheat was determined by the micro-Kjeldahl method (Westerman, 1990).

Of the 10 different treatment combinations (Table 2), five were selected for monitoring the dynamics of $\mathrm{NO}_{3}-\mathrm{N}$ and $\mathrm{NH}_{4}-\mathrm{N}$. These were $\mathrm{GM}_{0} \mathrm{FN}_{0}$ (Rice)-FN $\mathrm{FN}_{0}$ (Wheat), GM $\mathrm{FN}_{120}-\mathrm{FN}_{120}, \mathrm{GM}_{20} \mathrm{FN}_{0}-\mathrm{FN}_{0}, \mathrm{GM}_{20} \mathrm{FN}_{60}-\mathrm{FN}_{90}$, and $\mathrm{GM}_{40} \mathrm{FN}_{120}-$ $\mathrm{FN}_{90}$. Four cores were collected with a 5-cm-i.d. tube auger and composited separately for six soil depths $(0-15,15-30$, $30-60,60-90,90-120$, and $120-150 \mathrm{~cm})$ in 15 plots (5 treatments $\times 3$ replications) at initiation and completion of the 4-yr study. Following the same protocol, soil samples were periodically taken from the upper three soil depths $(0-15$, 15-30, and 30-60 cm) before and/or after important field operations during three cycles of the rice-wheat rotation to monitor the dynamics of $\mathrm{NH}_{4}-\mathrm{N}$ and $\mathrm{NO}_{3}-\mathrm{N}$ during and after each crop.

Field moist soil samples were thoroughly mixed, and representative subsamples were extracted immediately by shaking with $2 \mathrm{M} \mathrm{KCl}$ solution (1:6 soil/solution ratio) for $1 \mathrm{~h}$ on a mechanical shaker followed by filtration. The extracts were analyzed for $\mathrm{NH}_{4}-\mathrm{N}$ and $\left(\mathrm{NO}_{3}+\mathrm{NO}_{2}\right)-\mathrm{N}$ by a micro-Kjeldahl procedure (Mulvaney, 1996).

Bulk density $\left(D_{\mathrm{b}}\right)$ of the soils was determined to a $150-\mathrm{cm}$ depth with $5 \mathrm{~cm}$ i.d. by $15 \mathrm{~cm}$ long steel cores with open ends following the soil sampling protocol mentioned above for $\mathrm{N}$ dynamics. Bulk density measurements were made periodically during the $4 \mathrm{yr}$ of the experiment, and mean $D_{\mathrm{b}}$ values for five selected treatments were used for converting $\mathrm{NH}_{4}-\mathrm{N}$ and $\mathrm{NO}_{3}-\mathrm{N}$ concentrations ( $\mathrm{mg} \mathrm{N} \mathrm{kg}^{-1}$ soil) to units of $\mathrm{kg} \mathrm{N} \mathrm{ha}^{-1}$.

Statistical analysis of experimental data was accomplished by standard analysis of variance (ANOVA) in RCBD (Gomez and Gomez, 1976) using IRRISTAT software (Bartolome et al., 1999). As three of the 10 treatments were not included in Year 1, only data from Years 2, 3, and 4 for rice and wheat yields, $\mathrm{N}$ uptake and recovery, and harvest index (HI) were used for repeated-measure pooled analysis. The data for the $\mathrm{GM}_{0} \mathrm{FN}_{120}-\mathrm{FN}_{90}$ treatment were not included for 3-yr pooled analysis as this treatment was missing in Year 2 (Table 2). Using a paired $t$ test, no-N control $\left(\mathrm{GM}_{0} \mathrm{FN}_{0}-\mathrm{FN}_{0}\right)$ and $\mathrm{FN}$ $\left(\mathrm{GM}_{0} \mathrm{FN}_{120}-\mathrm{FN}_{120}\right)$ or control $\left(\mathrm{GM}_{0} \mathrm{FN}_{0}-\mathrm{FN}_{0}\right)$ and $\mathrm{GM}\left(\mathrm{GM}_{20}\right.$ $\mathrm{FN}_{0}-\mathrm{FN}_{0}$ ) treatments were compared for the data on $\mathrm{NH}_{4}-\mathrm{N}$ and $\mathrm{NO}_{3}-\mathrm{N}$ concentrations in the soil profile during rice and wheat crops. Harvest index of rice and wheat was calculated from the ratio grain yield/total yield (grain + straw). The fertilizer $\mathrm{N}$ equivalent (FNE) of GM in wetland rice is the quantity of FN that must be applied to obtain grain yield equal to that obtained with GM alone and was calculated following the procedure of Bouldin et al. (1984) and Yadvinder-Singh et al. (1995). First, from rice yield data obtained with different FN rates, the best-fit regression was searched using the scatter diagram technique and greatest $R^{2}$ values (Gomez and Gomez, 1976). Then quadratic regression equation $y=a x^{2}+b x+c$ was computed separately for each year using the regression module of IRRISTAT software (Bartolome et al., 1999). Where $y$ is rice grain yield $\left(\mathrm{Mg} \mathrm{ha}^{-1}\right)$ obtained with $\mathrm{FN}, x$ is applied FN $\left(\mathrm{kg} \mathrm{ha}^{-1}\right), a$ and $b$ are constants, and $c$ is an intercept. Thereafter, FNE of GM was calculated by solving the $x$ as follows

$$
x=\left\{b \pm\left[b^{2}-4 a(c-y)\right]^{1 / 2}\right\} / 2 a
$$

Where $y$ is the yield data obtained with the $\mathrm{GM}_{20}$ or $\mathrm{GM}_{40}$ rate. The same procedure was followed for computing FNE of GM using $\mathrm{N}$ uptake data.

Apparent $\mathrm{N}$ recovery (ANR) was calculated as follows

$$
\operatorname{ANR~}(\%)=\frac{\begin{array}{c}
\mathrm{N} \text { uptake from fertilizer or GM treatment } \\
\left(\mathrm{kg} \mathrm{N} \mathrm{ha}^{-1}\right)
\end{array}}{\text { Applied } \mathrm{N} \text { from fertilizer of } \mathrm{GM}\left(\mathrm{kg} \mathrm{N} \mathrm{ha}^{-1}\right)}
$$

\section{RESULTS AND DISCUSSION}

\section{Rice Yield}

Grain yield of rice was significantly greater in the plots treated with $120 \mathrm{~kg} \mathrm{FN} \mathrm{ha}{ }^{-1}\left(\mathrm{GM}_{0} \mathrm{FN}_{120}\right)$ than in the no-N control $\left(\mathrm{GM}_{0} \mathrm{FN}_{0}\right)$ plots $(5.40$ vs. $2.71 \mathrm{Mg}$ $\left.\mathrm{ha}^{-1}\right)$. Three-year pooled analysis of rice yields for Years 2 to 4 revealed that rice yields and $\mathrm{N}$ responses did not differ significantly between years (Table 3 ).

Incorporation of $20 \mathrm{Mg} \mathrm{GM} \mathrm{ha}{ }^{-1}$ without $\mathrm{FN}\left(\mathrm{GM}_{20}\right.$ $\mathrm{FN}_{0}$ ), which added from 77 to $128 \mathrm{~kg} \mathrm{~N} \mathrm{ha}^{-1}$ in the aboveground material (Table 4), produced $91 \%$ greater grain yield than the no-N control on average across $3 \mathrm{yr}$ (Table 3). Combined application of FN and GM showed a significant synergistic effect on rice grain yield in all years. Three-year mean rice grain yields for $60 \mathrm{~kg} \mathrm{FN}$ $\mathrm{ha}^{-1}\left(\mathrm{GM}_{0} \mathrm{FN}_{60}\right)$ and $120 \mathrm{~kg} \mathrm{FN} \mathrm{ha}^{-1}\left(\mathrm{GM}_{0} \mathrm{FN}_{120}\right)$ were 58 and $99 \%$ greater than the unfertilized control. The yields for $\mathrm{GM}_{20} \mathrm{FN}_{60}, \mathrm{GM}_{20} \mathrm{FN}_{120}, \mathrm{GM}_{40} \mathrm{FN}_{60}$, and $\mathrm{GM}_{40}$ $\mathrm{FN}_{120}$ were 2.13 to $3.03 \mathrm{Mg} \mathrm{ha}^{-1}$ greater than the control. Rice yield response to $\mathrm{GM}_{20}$ was greatest when applied with $\mathrm{FN}_{60}$, which yielded 8 to $17 \%$ more than the $\mathrm{GM}_{0}$ $\mathrm{FN}_{120}$ treatment, indicating that $\mathrm{GM}_{20}$ was more effective than $\mathrm{FN}_{60}$ in enhancing rice yield. The response to green manuring did not increase further when $\mathrm{GM}_{20}$ was applied in conjunction with $\mathrm{FN}_{120}$. With $\mathrm{GM}_{40} \mathrm{FN}_{120}$, yield was significantly lower than with $\mathrm{GM}_{0} \mathrm{FN}_{120}$. This may have been due to an excessive supply of $\mathrm{N}$ that produced excessive vegetative growth, as indicated by the high straw yield and decrease in HI from 0.44 to 0.39 (Table $3)$. This shift to greater early vegetative growth resulted in lodging of the crop and perhaps was the cause for reduction in rice grain yield.

\section{Fertilizer Nitrogen Equivalence of Green Manure and Substitution of Nitrogen}

Based on rice grain yields, the 3-yr mean FNE values of GM were $104 \mathrm{~kg} \mathrm{~N}^{-1}$ for the $20 \mathrm{Mg} \mathrm{ha}^{-1}$ rate and $138 \mathrm{~kg} \mathrm{~N}^{-1}$ for the $40 \mathrm{Mg} \mathrm{ha}^{-1}$ rate. This FNE value for $\mathrm{GM}_{20}$ corresponded with $24 \%$ greater than the total amount of $\mathrm{N}$ added through $20 \mathrm{Mg} \mathrm{GM} \mathrm{ha}^{-1}$ (Table 4). The 3-yr mean FNE values estimated from $\mathrm{N}$ uptake values were $113 \mathrm{~kg} \mathrm{~N}^{-1}$ for the $20 \mathrm{Mg} \mathrm{ha}^{-1}$ rate and $179 \mathrm{~kg} \mathrm{~N}^{-1}$ for the $40 \mathrm{Mg} \mathrm{ha}^{-1}$ rate. These FNEs were substantially greater than those obtained from rice grain yield, as $\mathrm{N}$ uptake data also included $\mathrm{N}$ used by rice straw. For example, the very high rice straw yield of $7.59 \mathrm{Mg} \mathrm{ha}^{-1}$ obtained with $40 \mathrm{Mg} \mathrm{GM} \mathrm{ha}^{-1}$ and the associated $\mathrm{N}$ uptake of $146 \mathrm{~kg} \mathrm{ha}^{-1}$ (Table 3) reflected the relatively high mean FNE value of $179 \mathrm{~kg} \mathrm{~N} \mathrm{ha}^{-1}$. These results suggest that the GM-N applied at $20 \mathrm{Mg}$ 
Table 3. Three-year (Years 2-4) mean rice grain and straw yield and total $\mathbf{N}$ uptake (grain + straw) as influenced by applied fertilizer N (FN) with and without green manure (GM).

\begin{tabular}{|c|c|c|c|c|c|}
\hline \multicolumn{2}{|c|}{ Treatment applied to $\dagger$} & \multicolumn{4}{|c|}{ Rice } \\
\hline Rice & Wheat & Grain yield & Straw yield & HI & Total N uptake \\
\hline & & 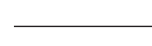 & $\overline{-}$ & & $\mathbf{k g ~ h a ~}^{-1}$ \\
\hline $\mathbf{G M}_{0} \mathbf{F N}_{0}$ & $\mathbf{F N}_{0}$ & 2.71 & 3.91 & 0.43 & 47 \\
\hline $\mathbf{G M}_{0} \mathbf{F N}_{60}$ & $\mathbf{F N}_{60}$ & 4.29 & 5.81 & 0.44 & 84 \\
\hline $\mathbf{G M}_{0} \mathbf{F N}_{120}$ & $\mathbf{F N}_{120}$ & 5.40 & 7.06 & 0.44 & 123 \\
\hline $\mathbf{G M}_{20} \mathbf{F} \mathbf{N}_{0}$ & $\mathbf{F N}_{0}$ & 5.18 & 6.84 & 0.44 & 114 \\
\hline $\mathbf{G M}_{20} \mathbf{F N}_{60}$ & $\mathbf{F N}_{90}$ & 5.74 & 7.58 & 0.44 & 134 \\
\hline $\mathbf{G M}_{20} \mathbf{F N}_{120}$ & $\mathbf{F N}_{90}$ & 5.70 & 7.91 & 0.42 & 148 \\
\hline $\mathbf{G M}_{40} \mathbf{F N}_{0}$ & $\mathbf{F N}_{0}$ & 5.81 & 7.59 & 0.43 & 146 \\
\hline $\mathbf{G M}_{40} \mathbf{F N}_{60}$ & $\mathbf{F N}_{90}$ & 5.39 & 7.55 & 0.41 & 148 \\
\hline $\mathbf{G M}_{40} \mathbf{F N}_{120}$ & $\mathbf{F N}_{90}$ & 4.84 & 7.54 & 0.39 & 143 \\
\hline \multicolumn{6}{|c|}{ Standard errors } \\
\hline \multirow{3}{*}{\multicolumn{2}{|c|}{$\begin{array}{l}\text { FN, GM, year } \\
\text { FN } \times \text { GM, FN } \times \text { year, GM } \times \text { year } \\
\text { FN } \times \mathbf{G M} \times \text { year }\end{array}$}} & 0.09 & 0.13 & 0.01 & 2 \\
\hline & & 0.13 & 0.28 & 0.01 & 4 \\
\hline & & 0.17 & 0.37 & 0.01 & 5 \\
\hline \multicolumn{6}{|c|}{ ANOVA results } \\
\hline \multicolumn{2}{|l|}{ FN, GM } & $* *$ & $* *$ & NS & $* *$ \\
\hline \multicolumn{2}{|l|}{ Year } & NS & $*$ & NS & $*$ \\
\hline & $*$ & $*$ & $*$ & * \\
\hline \multicolumn{2}{|c|}{ Year $\times$ FN, year $\times$ GM, year $\times \mathbf{F N} \times \mathbf{G M}$} & NS & NS & NS & NS \\
\hline
\end{tabular}

*, ** Significant at the 0.05 and 0.01 levels of probability, respectively; NS is not significant.

$\dagger$ GM is green manure and FN is fertilizer N; subscripts denote application rates (Mg ha ${ }^{-1}$ and $\mathrm{kg} \mathrm{ha}^{-1}$, respectively).

+ HI is harvest index (ratio of grain yield of total grain + straw yield).

$\mathrm{ha}^{-1}$ rate was better than $\mathrm{FN}$ in obtaining rice yields. The crop response to $\mathrm{GM}_{20} \mathrm{FN}_{60}$ resulted in an additional increase in rice grain yield that was higher than with $\mathrm{GM}_{0} \mathrm{FN}_{120}$, which is the optimum $\mathrm{N}$ rate for rice (Gill, 1995). This suggests that $\mathrm{GM}_{20}$ may enhance yield potential above that of FN alone, indicating a benefit of green manure beyond $\mathrm{N}$ supply. Possible explanations for this enhanced yield potential may include more favorable physical, chemical, and biological conditions, and nutrient availability in soils amended with GM (YadvinderSingh et al., 1988; Walters et al., 1992; Aulakh, 1994).

The narrow $\mathrm{C} / \mathrm{N}$ ratio of GM (Table 4) resulted in rapid mineralization and allowed the GM to serve as an efficient source of $\mathrm{N}$. This was reported earlier (Yadvinder-Singh et al., 1988; Aulakh et al., 1991) and was confirmed in a recent laboratory incubation study, where Khera et al. (1999) observed 36\% mineralization of sesbania GM-N within 15 d. Efficient use of GM-N may be due to the synchrony between $\mathrm{N}$ release from incorporated GMs and crop plant $\mathrm{N}$ demand. Also, unlike FN, GM-N is less prone to losses through leaching of $\mathrm{NO}_{3}$ beyond the rooting zone (see below).

\section{Residual Effects of Green Manure on Wheat}

Fertilizer N applied to wetland rice in subtropical, semiarid soils often has no residual effect on succeeding crops (Maskina et al., 1988), and a fresh application of
$120 \mathrm{~kg} \mathrm{FN} \mathrm{ha}^{-1}$ is recommended for wheat that follows wetland rice (Gill, 1995). However, information on the residual effects of green manures in rice-wheat systems is not available. In our study, the 3-yr mean wheat grain yield of $2.24 \mathrm{Mg} \mathrm{ha}^{-1}$ without FN and GM $\left(\mathrm{GM}_{0} \mathrm{FN}_{0}\right.$ $\mathrm{FN}_{0}$ ) increased to $4.53 \mathrm{Mg} \mathrm{ha}^{-1}$ with the $\mathrm{GM}_{0} \mathrm{FN}_{120}-\mathrm{FN}_{120}$ treatment (Table 5). Green manuring of rice exhibited a significant residual effect on the grain yield of wheat. Mean 3-yr yields of wheat increased $15 \%$ due to the residual effect of $20 \mathrm{Mg} \mathrm{GM} \mathrm{ha}{ }^{-1}\left(\mathrm{GM}_{20} \mathrm{FN}_{0}-\mathrm{FN}_{0}\right)$ applied to the preceding rice crop and $22 \%$ following $40 \mathrm{Mg} \mathrm{GM} \mathrm{ha}{ }^{-1}\left(\mathrm{GM}_{40} \mathrm{FN}_{0}-\mathrm{FN}_{0}\right)$. However, application of $120 \mathrm{~kg} \mathrm{FN} \mathrm{ha}^{-1}$ to wheat in plots not amended with GM $\left(\mathrm{GM}_{0} \mathrm{FN}_{120}-\mathrm{FN}_{120}\right)$ and $90 \mathrm{~kg} \mathrm{FN} \mathrm{ha}{ }^{-1}$ to wheat in $\mathrm{GM}_{20}$-amended plots $\left(\mathrm{GM}_{20} \mathrm{FN}_{120}-\mathrm{FN}_{90}\right)$ resulted in statistically equivalent wheat grain yields and $\mathrm{N}$ uptake (Table 5). These results suggest that the use of green manuring in a rice-wheat system may provide a similar effect as the application of $30 \mathrm{~kg} \mathrm{FN} \mathrm{ha}^{-1}$ to the following wheat crop and thus reduce its fertilizer $\mathrm{N}$ requirement by $\approx 25 \%$.

\section{Removal and Recovery of Nitrogen by Rice and Wheat}

Nitrogen uptake by rice was significantly increased by the application of FN and GM (Table 3). Mean 3 -yr total $\mathrm{N}$ uptake by rice grain and straw was $47 \mathrm{~kg}$

Table 4. Fresh and dry matter, and $\mathrm{N}$ additions from green manure $\dagger$ applied to rice.

\begin{tabular}{|c|c|c|c|c|c|}
\hline Year & Fresh matter & Dry matter & $N$ content & $\mathrm{C} / \mathrm{N}$ ratio & $\mathbf{N}$ addition \\
\hline & 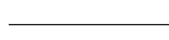 & - & $\mathbf{g ~ k g}^{-1}$ & & $\mathbf{k g ~ h a}^{-1}$ \\
\hline 1 & 25 & 4.25 & 30.1 & 16 & 128 \\
\hline 2 & 20 & 2.99 & 29.0 & 17 & 87 \\
\hline 3 & 20 & 3.30 & 23.2 & 20 & 77 \\
\hline 4 & 20 & 3.44 & 25.7 & 19 & 88 \\
\hline Mean $\pm \mathbf{S D}$ & $20 \pm 0.0$ & $3.24 \pm 0.2$ & $26.0 \pm 2.9$ & $19 \pm 2.0$ & $84 \pm 6.0$ \\
\hline
\end{tabular}

$\dagger$ Cowpea in Year 1 and sesbania in the other 3 yr.

$\$$ 3-yr (Years 2-4) mean \pm standard deviation. 
Table 5. Three-year (Years 2-4) mean wheat grain and straw yield and total $\mathrm{N}$ uptake (grain + straw) as influenced by applied fertilizer N (FN) with and without residual green manure (GM).

\begin{tabular}{|c|c|c|c|c|c|}
\hline \multicolumn{2}{|c|}{ Treatment applied to $\dagger$} & \multicolumn{4}{|c|}{ Wheat } \\
\hline Rice & Wheat & Grain yield & Straw yield & HIt & Total N uptake \\
\hline & & 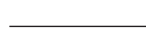 & 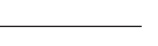 & & $\mathrm{kg} \mathrm{ha}^{-1}$ \\
\hline $\mathbf{G M}_{0} \mathbf{F N}_{0}$ & $\mathbf{F N}_{0}$ & 2.24 & 3.07 & 0.42 & 37 \\
\hline $\mathbf{G M}_{0} \mathbf{F N}_{60}$ & $\mathbf{F N}_{60}$ & 3.46 & 4.94 & 0.41 & 66 \\
\hline $\mathbf{G M}_{0} \mathbf{F N}_{120}$ & $\mathbf{F N}_{120}$ & 4.53 & 6.49 & 0.41 & 105 \\
\hline $\mathbf{G M}_{20} \mathbf{F N}_{0}$ & $\mathbf{F N} \mathbf{N}_{0}$ & 2.57 & 3.42 & 0.43 & 47 \\
\hline $\mathbf{G M}_{20} \mathbf{F N}_{60}$ & $\mathbf{F N}_{90}$ & 4.25 & 6.42 & 0.40 & 92 \\
\hline $\mathbf{G M}_{20} \mathbf{F N}_{120}$ & $\mathbf{F N}_{90}$ & 4.37 & 6.43 & 0.40 & 95 \\
\hline $\mathbf{G M}_{40} \mathbf{F N}_{0}$ & $\mathbf{F N}_{0}$ & 2.74 & 3.86 & 0.41 & 53 \\
\hline $\mathbf{G M}_{40} \mathbf{F N}_{60}$ & $\mathbf{F N}_{90}$ & 4.59 & 6.76 & 0.40 & 104 \\
\hline $\mathbf{G M}_{40} \mathbf{F N}_{120}$ & $\mathbf{F N}_{90}$ & 4.59 & 6.75 & 0.40 & 107 \\
\hline \multicolumn{6}{|l|}{ Standard errors } \\
\hline Treatment & & 0.14 & 0.40 & 0.01 & 3 \\
\hline Year & & 0.25 & 0.62 & 0.01 & 4 \\
\hline Treatment $\times$ year & & 0.37 & 0.81 & 0.02 & 7 \\
\hline \multicolumn{6}{|l|}{ ANOVA results } \\
\hline Treatment & & $* *$ & $* *$ & NS & $* *$ \\
\hline Year & & NS & * & NS & $*$ \\
\hline Treatment $\times$ year & & NS & NS & NS & NS \\
\hline
\end{tabular}

*, ** Significant at the 0.05 and 0.01 levels of probability, respectively; NS is not significant.

$\dagger$ GM is green manure and FN is fertilizer $\mathrm{N}$; subscripts denote application rates $\left(\mathrm{Mg} \mathrm{ha}^{-1}\right.$ and $\mathrm{kg} \mathrm{ha}^{-1}$, respectively).

$\$ \mathrm{HI}$ is harvest index (ratio of grain yield to total grain + straw yield).

$\mathrm{ha}^{-1}$ in the control $\left(\mathrm{FN}_{0}\right), 84 \mathrm{~kg} \mathrm{ha}^{-1}$ in $\mathrm{FN}_{60}, 123 \mathrm{~kg}$ $\mathrm{ha}^{-1}$ in $\mathrm{FN}_{120}, 114 \mathrm{~kg} \mathrm{ha}^{-1}$ in $\mathrm{GM}_{20}$ and $146 \mathrm{~kg} \mathrm{ha}^{-1}$ in the $\mathrm{GM}_{40}$ treatments. Mean 3-yr ANR from $\mathrm{FN}_{60}$ and $\mathrm{FN}_{120}$ by rice was 62 and $63 \%$, whereas for the $\mathrm{GM}_{20}$ and $\mathrm{GM}_{40}$ treatment, ANR was 79 and $59 \%$ (Table 6). Greater ANR of GM-N by rice at the $\mathrm{GM}_{20}$ rate than from the $\mathrm{FN}_{120}$ rate (79 vs. $63 \%$ ) further illustrates the better utilization of $\mathrm{N}$ applied as GM. However, at the $40 \mathrm{Mg} \mathrm{ha}^{-1}$ application rate, recovery of $\mathrm{N}$ from GM decreased to $59 \%$, perhaps due to a decrease in $\mathrm{N}$-use efficiency by rice resulting from $\mathrm{N}$ in excess of crop needs for optimum yield (Morris et al., 1989).

Three-year mean total $\mathrm{N}$ uptake by wheat grain and straw was $37 \mathrm{~kg} \mathrm{ha}^{-1}$ in the control, $66 \mathrm{~kg} \mathrm{ha}^{-1}$ in $\mathrm{FN}_{60}$, and $105 \mathrm{~kg} \mathrm{ha}^{-1}$ in $\mathrm{FN}_{120}$ treatments (Table 5). The $\mathrm{N}$ uptake with residual $\mathrm{GM}_{20}$ was $47 \mathrm{~kg} \mathrm{ha}^{-1}$ and $\mathrm{GM}_{40}$ was $53 \mathrm{~kg} \mathrm{ha}^{-1}$. The 3-yr mean ANR by wheat for the $\mathrm{FN}_{60}$ and $\mathrm{FN}_{120}$ treatments was 53 and $57 \%$ (Table 6).
Three-year mean recovery of residual GM-N by wheat for the $\mathrm{GM}_{20}$ rate was $11 \%$ and $\mathrm{GM}_{40}$ rate was $16 \%$. The increase in wheat yield due to the supply of $\mathrm{N}$ by residual GM was supported by soil mineral $\mathrm{N}$ data discussed below.

\section{Dynamics of Ammonium and Nitrate in Soil}

In general, the amount of $\mathrm{NH}_{4}-\mathrm{N}$ and $\mathrm{NO}_{3}-\mathrm{N}$ in the soil showed significant increases after application of urea to rice or wheat during different years. For example, Year 2 data for one rice-wheat cycle presented in Fig. 1 illustrate that early-season rises in the amount of $\mathrm{NH}_{4}-\mathrm{N}$, and $\mathrm{NO}_{3}-\mathrm{N}$ were generally greatest in the surface layer $(0-15 \mathrm{~cm})$ and less prominent in the $15-$ to $30-$ and $30-$ to $60-\mathrm{cm}$ layers. Nevertheless, rapid distribution of applied FN to lower soil depths in this irrigated porous soil was evident. In all layers, the amount of

Table 6. Apparent $\mathrm{N}$ recovery by rice and wheat from fertilizer and green manure.

\begin{tabular}{|c|c|c|c|c|c|}
\hline Treatment & Year 1 & Year 2 & Year 3 & Year 4 & Mean $\pm \mathbf{S D} \dagger$ \\
\hline & \multicolumn{5}{|c|}{ Apparent $\mathbf{N}$ recovery by rice } \\
\hline \multicolumn{6}{|c|}{ Fertilizer $\mathbf{N}\left(\mathrm{kg} \mathrm{ha}^{-1}\right)$} \\
\hline $\begin{array}{l}60 \\
120\end{array}$ & $\begin{array}{l}62 \\
54\end{array}$ & $\begin{array}{l}50 \\
60\end{array}$ & $\begin{array}{l}75 \\
66\end{array}$ & $\begin{array}{l}60 \\
63\end{array}$ & $\begin{array}{l}62 \pm 13 \\
63 \pm 3\end{array}$ \\
\hline \multicolumn{6}{|c|}{ Green manure $\left(\mathrm{Mg} \mathrm{ha}^{-1}\right)$} \\
\hline \multirow[t]{2}{*}{$\begin{array}{l}20 \\
40\end{array}$} & $\begin{array}{c}50 \\
+\end{array}$ & $\begin{array}{l}78 \\
52\end{array}$ & $\begin{array}{l}85 \\
70\end{array}$ & $\begin{array}{l}75 \\
55\end{array}$ & $\begin{array}{l}79 \pm 6 \\
59 \pm 13\end{array}$ \\
\hline & \multicolumn{5}{|c|}{ Apparent $\mathrm{N}$ recovery by wheat } \\
\hline \multicolumn{6}{|c|}{ Fertilizer $\mathbf{N}\left(\mathrm{kg} \mathrm{ha}^{-1}\right)$} \\
\hline $\begin{array}{l}60 \\
120\end{array}$ & $\begin{array}{l}76 \\
66\end{array}$ & $\begin{array}{l}59 \\
64\end{array}$ & $\begin{array}{l}45 \\
47\end{array}$ & $\begin{array}{l}56 \\
59\end{array}$ & $\begin{array}{l}53 \pm 7 \\
57 \pm 8\end{array}$ \\
\hline \multicolumn{6}{|c|}{ Residual green manure $\left(\mathrm{Mg} \mathrm{ha}^{-1}\right)$} \\
\hline $\begin{array}{l}20 \\
40\end{array}$ & $\begin{array}{c}6 \\
+\end{array}$ & $\begin{array}{l}15 \\
11\end{array}$ & $\begin{array}{r}5 \\
13\end{array}$ & $\begin{array}{l}14 \\
24\end{array}$ & $\begin{array}{l}11 \pm 5 \\
16 \pm 7\end{array}$ \\
\hline
\end{tabular}

$\dagger$ 3-yr (Years 2-4) mean \pm standard deviation.

$\$$ Treatment was not included. 
(a)
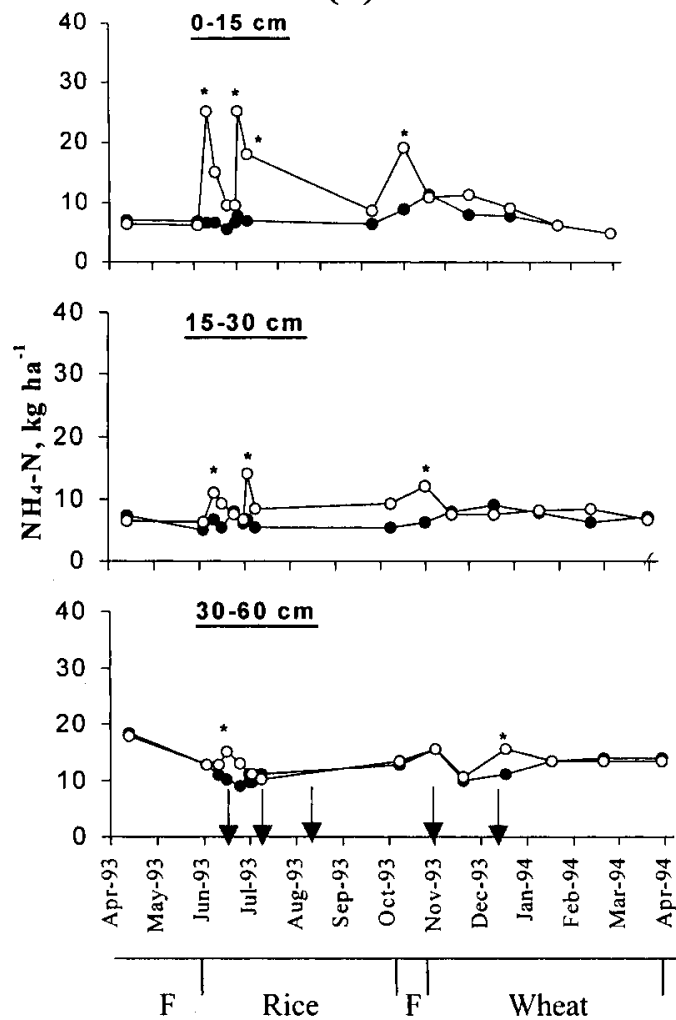

$\mathrm{GM}_{0} \mathrm{FN}_{\mathrm{O}}-\mathrm{FN} \mathrm{N}_{\mathrm{O}}$

$\mathbf{G M}_{0} \mathrm{FN}_{120}-\mathrm{FN}_{120}$
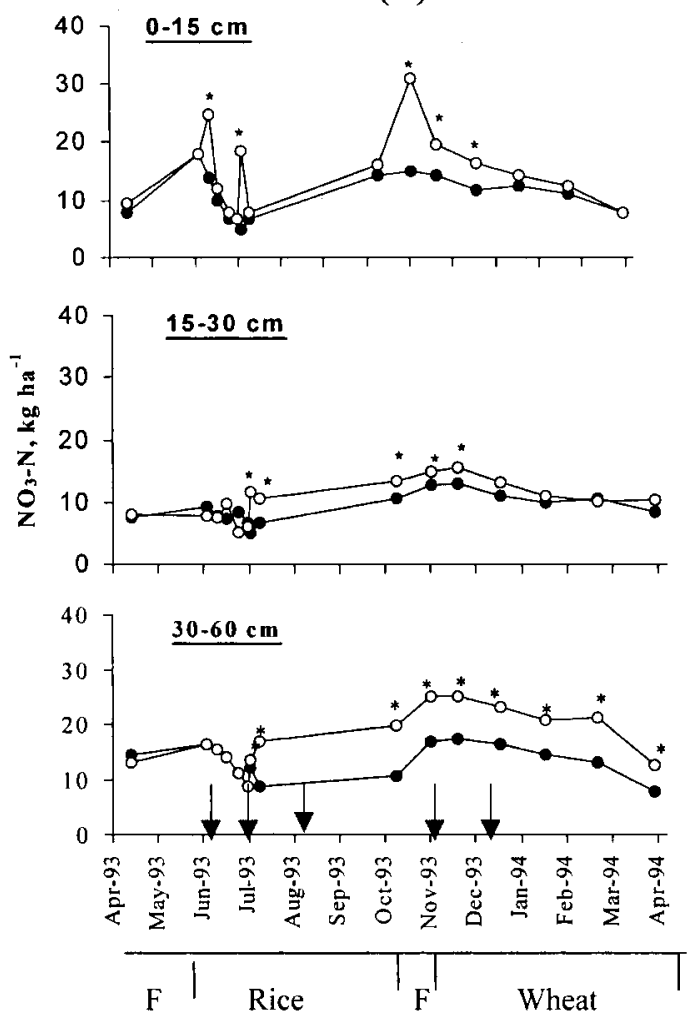

Fig. 1. Dynamics of (a) $\mathbf{N H}_{4}-\mathrm{N}$ and (b) $\mathbf{N O}_{3}-\mathbf{N}$ in three soil layers of no-N control $\left(G^{-} \mathbf{M}_{0} \mathbf{F N}_{0}-\mathbf{F N}_{0}\right)$ and fertilizer $\mathbf{N}\left(\mathbf{G M}_{0} \mathbf{F N}_{120}-\mathbf{F N} \mathbf{N}_{120}\right)$ treatment in a rice-wheat cropping system during Year 2 (1993-1994). GM is green manure and FN is fertilizer N; subscripts denote application rates $\left(\mathrm{Mg} \mathrm{ha}^{-1}\right.$ and $\mathrm{kg} \mathrm{ha}^{-1}$, respectively). Arrows denote fertilizer $\mathrm{N}$ application. * Indicates significant difference $(P \leq 0.05)$ between no-N control and fertilizer $\mathrm{N}$ treatment. The periods under fallowing (F), rice, and wheat are marked on the $x$ axis.

$\mathrm{NH}_{4}-\mathrm{N}$ or $\mathrm{NO}_{3}-\mathrm{N}$ differed significantly between no$\mathrm{N}\left(\mathrm{GM}_{0} \mathrm{FN}_{0}-\mathrm{FN}_{0}\right)$ and fertilizer $\mathrm{N}\left(\mathrm{GM}_{0} \mathrm{FN}_{120}-\mathrm{FN}_{120}\right)$ treatments according to paired $t$ tests.

It should be noted that the greater amount of $\mathrm{NH}_{4}-\mathrm{N}$ and $\mathrm{NO}_{3}-\mathrm{N}$ in the $30-$ to $60-\mathrm{cm}$ layer was due to its greater thickness (and hence soil mass) than the 0- to $15-$ and $15-$ to $30-\mathrm{cm}$ layers. Increases in mineral $\mathrm{N}$ $\left[\left(\mathrm{NH}_{4}+\mathrm{NO}_{3}\right)-\mathrm{N}\right]$ in the 0 - to $15-, 15-$ to $30-$ and 30 - to $60-\mathrm{cm}$ soil layers after fertilizer application were often similar to the amount of $\mathrm{N}$ applied. For instance, the 23 June 1993 sample date, which occurred $2 \mathrm{~d}$ after the application of $40 \mathrm{~kg} \mathrm{FN} \mathrm{ha}^{-1}$ (1/3 split dose) to rice, resulted in an increase of $39 \mathrm{~kg} \mathrm{NH}_{4}-\mathrm{N}$ and $9 \mathrm{~kg} \mathrm{NO}_{3}-\mathrm{N}$ $\mathrm{ha}^{-1}$ in the soil profile of the $\mathrm{GM}_{0} \mathrm{FN}_{120}-\mathrm{FN}_{120}$ treatment more than that of the $\mathrm{GM}_{0} \mathrm{FN}_{0}-\mathrm{FN}_{0}$ control (Fig. 1). Similarly, a basal application of $60 \mathrm{~kg} \mathrm{FN} \mathrm{ha}^{-1}$ (1/2 split dose) to wheat on 6 Nov. 1993 resulted in an increase of $16 \mathrm{~kg} \mathrm{NH}_{4}-\mathrm{N}$ and $36 \mathrm{~kg} \mathrm{NO}_{3}-\mathrm{N} \mathrm{ha}^{-1}$ when sampled 5 d later on 11 Nov. 1993 (Fig. 1). The distribution of applied FN in the 0- to $60-\mathrm{cm}$ soil depth within 1 to $5 \mathrm{~d}$ was followed by a decrease in mineral $\mathrm{N}$ concentrations, probably due to crop uptake or denitrification losses (Aulakh et al., 1992). However, these data suggest that mineral $\mathrm{N}$ determination in irrigated porous soils is most reliable when soil is sampled to a $60-\mathrm{cm}$ depth instead of the current practice of only sampling to 15- or 30-cm depths (Anonymous, 1990).
After each FN application to the rice crop (JuneAugust), $\mathrm{NH}_{4}-\mathrm{N}$ usually exceeded $\mathrm{NO}_{3}-\mathrm{N}$ (Fig. 1), presumably due to reduced nitrification in the partially anaerobic soil systems that resulted from frequent irrigations. However, increased levels of $\mathrm{NO}_{3}-\mathrm{N}$ in soil were frequently observed 1 to $5 \mathrm{~d}$ after each $\mathrm{FN}$ application. During the period of upland wheat growth (November-early April), the amount of $\mathrm{NO}_{3}-\mathrm{N}$ increased rapidly after FN application (Fig. 1b). These results confirmed findings of earlier controlled-environment studies that nitrification of applied ammoniacal $\mathrm{N}$ in subtropical near neutral soils is very rapid under aerobic conditions (Kuldip-Singh et al., 1996) and that such porous soils under partially anaerobic condition can support substantial nitrification of applied ammoniacal $\mathrm{N}$ (Aulakh et al., 1996).

\section{Mineralization of Green Manure Nitrogen and Soil Organic Nitrogen during Fallow}

Incorporation of fresh GM $2 \mathrm{~d}$ prior to transplanting rice was associated with rapid accumulation of mineral $\mathrm{N}$ in soil, mostly as $\mathrm{NH}_{4}-\mathrm{N}$, for 1 to $2 \mathrm{wk}$, followed by a slow decline during a 2- to 3-wk period (Fig. 2). Rapid mineralization of GM-N was supported by the accumulation of $103 \mathrm{~kg}$ mineral $\mathrm{N}\left(\mathrm{NH}_{4}+\mathrm{NO}_{3}\right) \mathrm{ha}^{-1}$ on 23 June 1993 (5 d after GM incorporation) in the $\mathrm{GM}_{20}$ 

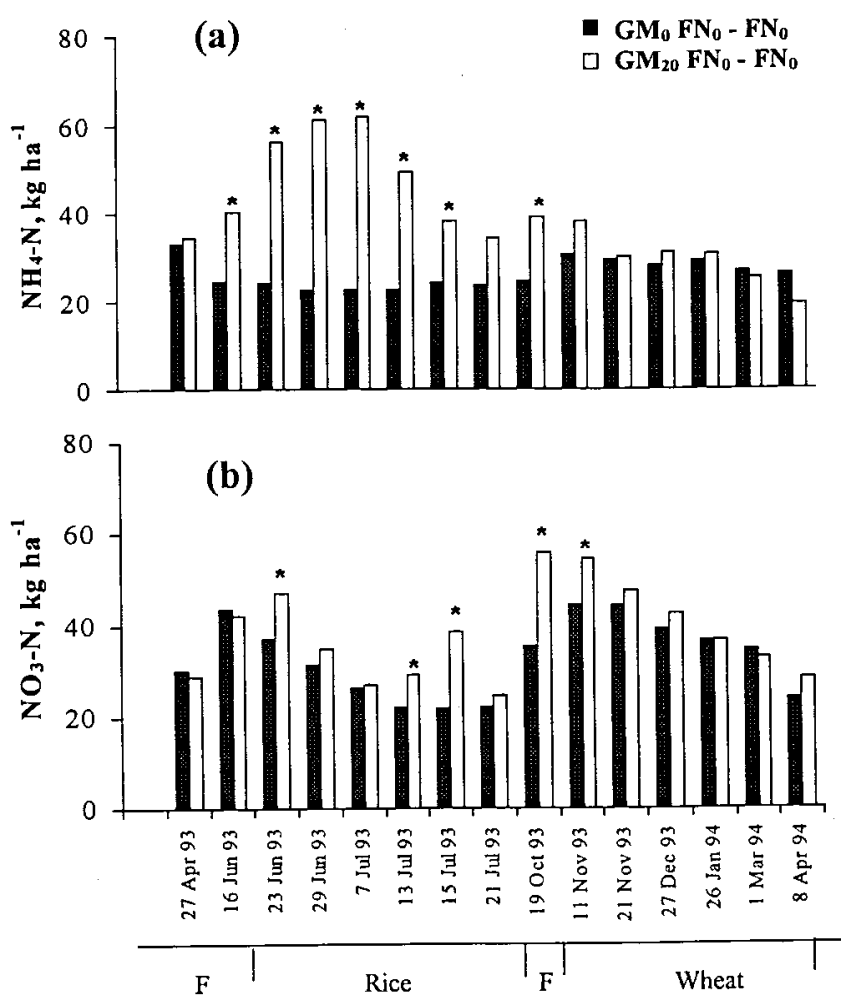

Fig. 2. Total amount of (a) $\mathrm{NH}_{4}-\mathrm{N}$ and (b) $\mathrm{NO}_{3}-\mathrm{N}$ in the $60-\mathrm{cm}$ soil profile of no- $\mathrm{N}$ control $\left(\mathbf{G M}_{0} \mathbf{F N}_{0}-\mathbf{F N}_{0}\right)$ and green manure $\left(\mathbf{G M}_{20}\right.$ $\mathrm{FN}_{0}-\mathrm{FN}_{0}$ ) treatment in a rice-wheat cropping system during Year 2 (1993-1994). GM is green manure and FN is fertilizer N; subscripts denote application rates $\left(\mathrm{Mg} \mathrm{ha}^{-1}\right.$ and $\mathrm{kg} \mathrm{ha}^{-1}$, respectively). *Indicates significant difference $(P \leq 0.05)$ between no-N control and green manure treatment. The periods under fallowing $(F)$, rice, and wheat are marked on the $x$ axis.

treatment, as compared with $56 \mathrm{~kg} \mathrm{~N} \mathrm{ha}^{-1}$ for the $\mathrm{GM}_{0}$ soil in Year 2 (Fig. 2). Similar results occurred in Year 3 with accumulation of $106 \mathrm{~kg}$ mineral $\mathrm{N} \mathrm{ha}^{-1}$ on 28 June 1994 (14 d after GM incorporation), as compared with $76 \mathrm{~kg} \mathrm{~N} \mathrm{ha}^{-1}$ in $\mathrm{GM}_{0}$ treatments (data not shown). As mentioned above, Khera et al. (1999) measured 36\% mineralization of sesbania GM-N within $15 \mathrm{~d}$ in growth chamber studies conducted at $35^{\circ} \mathrm{C}$. The rapid mineralization of GM-N explains the enhanced efficiency of GM, compared with FN, in supplying $\mathrm{N}$ to growing plants and increasing rice yields, $\mathrm{N}$ uptake, and $\mathrm{N}$ recovery. After a 3-wk post-rice fallow period, the top $60 \mathrm{~cm}$ of soil in the $\mathrm{GM}_{20} \mathrm{FN}_{0}$ treatment contained $17 \mathrm{~kg}$ more mineral $\mathrm{N} \mathrm{ha}^{-1}$ than the control $\left(\mathrm{GM}_{0} \mathrm{FN}_{0}\right)$ soil on 11 November (Fig. 2), presumably due to the mineralization of residual GM. These results suggest that mineralization of residual GM-N to the succeeding wheat crop reduced the fertilizer input by $25 \%$ for optimum wheat yield.

Mineralization of soil organic N (including leftover crop stubbles) during the two fallow periods after harvest of rice (October-November) and wheat (AprilJune) was apparent from the accumulation of $\mathrm{NO}_{3}-\mathrm{N}$ in soil. In Year 1 , mineral $\mathrm{N}$ increased by $14 \mathrm{~kg} \mathrm{~N} \mathrm{ha}{ }^{-1}$ in the $\mathrm{GM}_{0} \mathrm{FN}_{0}-\mathrm{FN}_{0}$ soil, from 68 to $82 \mathrm{~kg} \mathrm{~N}^{-1}$ between 22 Oct. and 19 Nov. 1992 (data not shown). In Year 2, after the harvest of rice on 9 Oct. 1993, mineral
Table 7. Nitrate- $\mathbf{N}$ in different layers of the soil profile after the harvest of rice and wheat after 2 yr of the rice-wheat crop rotation.

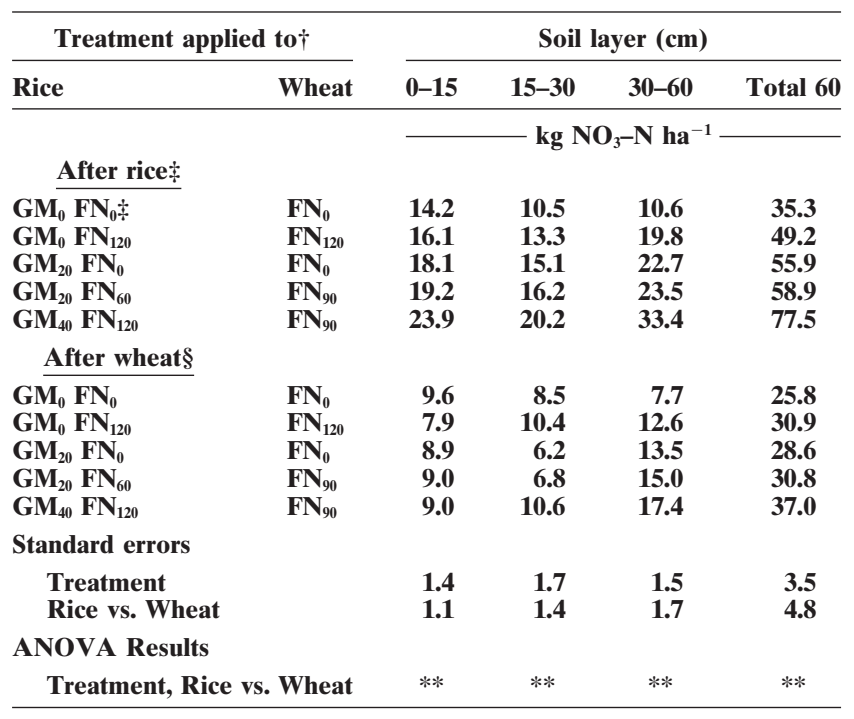

* Significant at the 0.01 level of probability.

$\dagger$ GM is green manure and FN is fertilizer $\mathbf{N}$; subscripts denote application rates $\left(\mathrm{Mg} \mathrm{ha}^{-1}\right.$ and $\mathrm{kg} \mathrm{ha}^{-1}$, respectively).

† Sampled on 19 Oct. 1993.

$\S$ Sampled on 8 Apr. 1994.

$\mathrm{N}$ in the 0 - to $60-\mathrm{cm}$ soil profile of no- $\mathrm{N}$ plots increased by $16 \mathrm{~kg} \mathrm{~N} \mathrm{ha}^{-1}$ from 59 to $75 \mathrm{~kg} \mathrm{~N} \mathrm{ha}^{-1}$ between 19 Oct. and 11 Nov. 1993 (Fig. 2). Similarly, after wheat harvest on 10 Apr. 1993, mineral $\mathrm{N}$ in the no- $\mathrm{N}$ plots increased by $9 \mathrm{~kg} \mathrm{~N} \mathrm{ha}^{-1}$ from $62 \mathrm{~kg} \mathrm{~N} \mathrm{ha}^{-1}$ on $27 \mathrm{Apr}$. 1993 to $71 \mathrm{~kg} \mathrm{~N} \mathrm{ha}^{-1}$ on 16 June 1993 . These results illustrate that despite low organic matter of most subtropical soils, such as the one used in our study (3.8 $\mathrm{g}$ OC $\mathrm{kg}^{-1}$ soil), a modest amount of $\mathrm{N}$ can be supplied to produce crop grain and straw yields of 4 to $5 \mathrm{Mg}$ $\mathrm{ha}^{-1}$ annually.

\section{Effects of Rice and Wheat on Ammonium and Nitrate Distribution in the Soil Profile}

The distributions of $\mathrm{NO}_{3}-\mathrm{N}$ and $\mathrm{NH}_{4}-\mathrm{N}$ in different soil layers changed frequently; however, changes in $\mathrm{NH}_{4}-\mathrm{N}$ in subsurface layers $(15-30$ and $30-60 \mathrm{~cm})$ were relatively small compared with those of $\mathrm{NO}_{3}-\mathrm{N}$ (Fig. 1 and 2). For example, data after rice harvest of Year 2 presented in Table 7 illustrate that $\mathrm{NO}_{3}-\mathrm{N}$ present in the $60-\mathrm{cm}$ soil profile was significantly greater in $\mathrm{GM}_{0}$ $\mathrm{FN}_{120}-\mathrm{FN}_{120}(39 \%), \mathrm{GM}_{20} \mathrm{FN}_{0}-\mathrm{FN}_{0}(58 \%), \mathrm{GM}_{20} \mathrm{FN}_{90}-$ $\mathrm{FN}_{90}(67 \%)$, and $\mathrm{GM}_{40} \mathrm{FN}_{120}-\mathrm{FN}_{90}$ treatments $(120 \%)$ than in $\mathrm{GM}_{0} \mathrm{FN}_{0}-\mathrm{FN}_{0}$. Further, the amount of $\mathrm{NO}_{3}-\mathrm{N}$ remaining in different soil layers after rice harvest was 37 to $109 \%$ greater than after wheat harvest (Table 7). Rice, a shallow-rooted crop, primarily uses nutrients in the surface soil layer and allows $\mathrm{NO}_{3}-\mathrm{N}$ to move deeper in the soil, where it is prone to loss via leaching to groundwater (Bajwa et al., 1993; Aulakh, 1994). However, significant amounts of the $\mathrm{NO}_{3}-\mathrm{N}$ from all soil layers up to $60-\mathrm{cm}$ depth were used by wheat following rice because of its deeper and more extensive rooting system that enables it to take up $\mathrm{N}$ from lower soil 
Table 8. Nitrate- $\mathbf{N}$ in the soil profile before and after $4 \mathrm{yr}$ of fertilizer $\mathrm{N}$ and green manure treatments in rice-wheat rotation.

\begin{tabular}{|c|c|c|c|c|c|c|c|c|}
\hline \multicolumn{2}{|c|}{ Treatment applied to $\dagger$} & \multicolumn{7}{|c|}{ Soil layer (cm) } \\
\hline \multirow[t]{2}{*}{ Rice } & \multirow[t]{2}{*}{ Wheat } & 0-15 & 15-30 & $30-60$ & $60-90$ & 90-120 & 120-150 & Total 150 \\
\hline & & \multicolumn{7}{|c|}{$\mathrm{kg} \mathrm{NO}_{3}-\mathrm{N} \mathrm{ha}^{-1}$} \\
\hline At beginning $\ddagger$ & & 7.0 & 7.1 & 13.5 & 10.2 & 13.5 & 14.5 & 65.8 \\
\hline \multicolumn{9}{|l|}{ After 4 yr§ } \\
\hline $\mathbf{G M}_{0} \mathbf{F N}_{0} \S$ & $\mathbf{F N}_{0}$ & 9.1 & 6.8 & 8.7 & 8.7 & 12.1 & 13.5 & 58.9 \\
\hline $\mathbf{G M}_{\mathbf{0}} \mathbf{F N}_{120}$ & $\mathbf{F N}_{120}$ & 8.7 & 6.8 & 13.5 & 13.5 & 23.2 & 28.0 & 93.7 \\
\hline $\mathbf{G M}_{20} \mathbf{F N}_{0}$ & $\mathbf{F N}$ & 7.1 & 5.8 & 13.5 & 12.6 & 18.4 & 17.4 & 74.8 \\
\hline $\mathbf{G M}_{20} \mathbf{F N}_{60}$ & $\mathbf{F N}_{90}$ & 8.0 & 6.0 & 13.5 & 13.0 & 19.2 & 18.2 & 77.9 \\
\hline $\mathbf{G M}_{40} \mathbf{F N}_{120}$ & $\mathbf{F N}_{90}$ & 9.2 & 5.8 & 13.5 & 17.4 & 23.2 & 31.9 & 101.0 \\
\hline \multicolumn{9}{|l|}{ Standard errors\# } \\
\hline Treatment & & 1.1 & 1.0 & 1.0 & 1.6 & 2.4 & 2.6 & 5.0 \\
\hline \multicolumn{9}{|l|}{ ANOVA results } \\
\hline Treatment & & NS & NS & $* *$ & * & * & $* *$ & * \\
\hline
\end{tabular}

* Significant at the 0.05 and 0.01 levels of probability, respectively; NS is not significant.

$\dagger$ GM is green manure and FN is fertilizer N; subscripts denote application rates ( $\mathrm{Mg} \mathrm{ha}^{-1}$ and $\mathrm{kg} \mathrm{ha}^{-1}$, respectively).

† Sampled on 18 Apr. 1992.

$\S$ Sampled on 20 Apr. 1996.

\# Analysis of variance included values at beginning and end of the study.

layers (Bijay-Singh and Sekhon, 1977). From these data, however, it is not possible to verify such effects of wheat beneath the $60-\mathrm{cm}$ soil depth.

In earlier studies with porous soils, substantial leaching of $\mathrm{NO}_{3}-\mathrm{N}$ below the root zone was observed from fields under heavily fertilized shallow-rooted crops such as maize (Arora et al., 1980) and potato (Solanum tuberosum L.) (Bijay-Singh and Sekhon, 1977). Based on groundwater $\mathrm{NO}_{3}-\mathrm{N}$ analysis of 236 samples collected from 21- to 38-m-deep tubewells located in different areas of Punjab state, Bajwa et al. (1993) observed that $17 \%$ of samples containing $>5 \mathrm{mg} \mathrm{NO}-\mathrm{N} \mathrm{L}^{-1}$ were obtained from tubewells located in vegetable growing areas, as compared with only $3 \%$ of samples from regions where rice-wheat rotation is practiced. The results of our study with a rice-wheat system demonstrate that rooting patterns of crops can strongly influence $\mathrm{NO}_{3}$ accumulation in the soil profile, and wheat following rice could reduce the potential hazard of $\mathrm{NO}_{3}$ leaching to deeper soil layers and groundwater.

\section{Leaching of Ammonium and Nitrate}

The amount of $\mathrm{NH}_{4}-\mathrm{N}$ and $\mathrm{NO}_{3}-\mathrm{N}$ present in different layers of soil at the end of four cycles of a rice-wheat rotation revealed that the different amounts of applied $\mathrm{FN}$ and incorporated $\mathrm{GM}$ did not affect $\mathrm{NH}_{4}-\mathrm{N}$ content of the soil profile to $150 \mathrm{~cm}$ (data not shown) but resulted in significant differences in $\mathrm{NO}_{3}-\mathrm{N}$ ranging from 59 to $101 \mathrm{~kg} \mathrm{~N} \mathrm{ha}^{-1}$ (Table 8). Application of the recommended rate of $120 \mathrm{~kg} \mathrm{FN} \mathrm{ha}^{-1}$ to both rice and wheat $\left(\mathrm{GM}_{0} \mathrm{FN}_{120}-\mathrm{FN}_{120}\right)$ in split applications for $4 \mathrm{yr}$ resulted in a significant increase of $35 \mathrm{~kg} \mathrm{NO}_{3}-\mathrm{N} \mathrm{ha}^{-1}$ greater than the no-N control, $74 \%$ of this increase occurred in the $90-$ to $150-\mathrm{cm}$ soil depth. The increase of $16 \mathrm{~kg}$ $\mathrm{NO}_{3}-\mathrm{N}^{-1}$ with the $\mathrm{GM}_{20} \mathrm{FN}_{0}-\mathrm{FN}_{0}$ and $19 \mathrm{~kg} \mathrm{NO}_{3}-\mathrm{N}$ ha ${ }^{-1}$ with the $\mathrm{GM}_{20} \mathrm{FN}_{60}-\mathrm{FN}_{90}$ treatment was not significant. However, incorporation of $40 \mathrm{Mg} \mathrm{GM} \mathrm{ha}{ }^{-1}$ in conjunction with $120 \mathrm{~kg} \mathrm{~N} \mathrm{ha}^{-1}$ in rice $\left(\mathrm{GM}_{40} \mathrm{FN}_{120}-\mathrm{FN}_{90}\right)$ resulted in a residual of $42 \mathrm{~kg} \mathrm{NO}_{3}-\mathrm{N} \mathrm{ha}^{-1}$ greater than the control; $70 \%$ of this $\mathrm{NO}_{3}-\mathrm{N}$ was located in the 90 to $150-\mathrm{cm}$ soil layer, subject to leaching to deeper soil layers and subsequent $\mathrm{NO}_{3}$ contamination of groundwater. The wheat crop that followed rice in this treatment only received $90 \mathrm{~kg} \mathrm{FN} \mathrm{ha}^{-1}, 75 \%$ of the recommended $\mathrm{N}$ rate, but produced dry matter, grain, and $\mathrm{N}$ yields that were similar to a wheat crop supplied with $120 \mathrm{~kg}$ $\mathrm{FN} \mathrm{ha}^{-1}$ (Table 5). However, all $\mathrm{NO}_{3}-\mathrm{N}$ reserves in the soil profile, especially in the $90-$ to $150-\mathrm{cm}$ layer, were not removed by the wheat crop. Perhaps the amount of $\mathrm{NO}_{3}-\mathrm{N}$ present in the soil profile was in excess of wheat crop needs or was moved beyond the active zone for nutrient absorption by roots. Because farmers tend to apply $\mathrm{N}$ in excess of crop requirements (Aulakh and Bijay-Singh, 1997), this could cause alarming groundwater contamination in some cases, as indicated by earlier reports (Singh et al., 1987; Singh, 1992). The results of this study clearly demonstrate that excess $\mathrm{N}$ applied through FN and GM reduces crop yields and results in leaching of $\mathrm{NO}_{3}$ to deeper soil layers. A major portion of enhanced soil $\mathrm{NO}_{3}(70-74 \%)$ occurring in the 90 - to $150-\mathrm{cm}$ depth indicates the possibility of $\mathrm{NO}_{3}$ leaching below $150 \mathrm{~cm}$ and into groundwater. However, $\mathrm{NO}_{3}-\mathrm{N}$ enrichment of the groundwater lifted by the tubewell located in the vicinity of the present experimental site, which was used for irrigation, remained uncontaminated. Groundwater $\mathrm{NO}_{3}$ levels should be closely watched in the future; if $\mathrm{NO}_{3}$ leaching occurs below $150 \mathrm{~cm}$, groundwater might become a significant contributor to $\mathrm{N}$ fertilization of crops but be unfit for human and animal consumption.

\section{CONCLUSIONS AND RECOMMENDATIONS}

Results of this 4-yr field study with an irrigated ricewheat system in a semiarid, subtropical soil low in organic $\mathrm{C}$ support several conclusions that may have useful agronomic and environmental implications. Our results indicate that supply of nutrients through the integrated use of $20 \mathrm{Mg} \mathrm{GM}$ and $60 \mathrm{~kg} \mathrm{FN} \mathrm{ha}^{-1}$ provides advantages over the use of FN alone, producing greater yields of rice and wheat while reducing the use of $\mathrm{FN}$ by $>50 \%$ 
in rice and $25 \%$ in wheat. By adopting the use of GM alone, the farmer can attain rice yields comparable with those produced with the recommended fertilizer rate of $120 \mathrm{~kg} \mathrm{FN} \mathrm{ha}^{-1}$. Under aerobic soil conditions, accumulation of 9 to $16 \mathrm{~kg} \mathrm{~N} \mathrm{ha}^{-1}$ mineral $\mathrm{N}$ in unfertilized control soils in a 4- to 8-wk fallow period demonstrated the modest capacity of such soils to supply sufficient $\mathrm{N}$ to produce crop grain and straw yields of 4 to $5 \mathrm{Mg}$ $\mathrm{ha}^{-1}$ annually. Rapid movement of applied FN to lower soil depths suggests that mineral $\mathrm{N}$ determination in such soils would be most reliable when soil is sampled to a $60-\mathrm{cm}$ depth instead of the current practice of only sampling to the 15- or 30-cm depths. Mineralization of green manure $\mathrm{N}$ was quite rapid and resulted in a similar or enhanced plant $\mathrm{N}$-use efficiency than that obtained with FN. A strong influence of FN application, incorporation of GM, rooting pattern of crops, and anaerobic and upland soil conditions was evident on the dynamics and distribution patterns of $\mathrm{NO}_{3}-\mathrm{N}$ in the soil profile and its potential for leaching beyond the root zone. The use of $20 \mathrm{Mg} \mathrm{ha}^{-1}$ of legume GM in conjunction with $60 \mathrm{~kg} \mathrm{FN} \mathrm{ha}{ }^{-1}$ to achieve an optimum nutrient supply for rice could significantly reduce $\mathrm{NO}_{3}$ leaching in soil, providing environmental benefits in addition to agronomic effects. However, the use of excessive FN in conjunction with GM will reduce fertilizer-use efficiency, may lower crop yields due to lodging from excessive vegetative growth, and can result in substantial $\mathrm{NO}_{3}$ leaching below the rooting zone, increasing the potential for $\mathrm{NO}_{3}$ contamination of groundwater. This study demonstrated that the rooting pattern of crops exerts a profound influence in controlling $\mathrm{NO}_{3}$ distribution pattern and leaching in the soil profile. Therefore, shallowrooted rice grown in rotation with wheat, which has a deeper and more extensive root system, appears a promising approach to efficiently use residual $\mathrm{N}$ and minimize leaching of $\mathrm{NO}_{3}$ to greater soil depths in irrigated porous soils.

\section{ACKNOWLEDGMENTS}

We gratefully acknowledge the financial assistance received from the Office of International Cooperation and Development, USDA, and the suggestions and critical review of an earlier version of this manuscript by Dr. Wally Wilhelm, USDA-ARS, University of Nebraska, Lincoln, NE; Dr. Changsheng. Li, University of New Hampshire, Durham, NH; and Dr. Kevin Bronson, Texas A\&M University, Lubbock, TX.

\section{REFERENCES}

Anonymous. 1990. Guidelines for collecting soil samples for soil testing. Soil Testing Laboratory, Dep. of Soils, Punjab Agricultural Univ., Ludhiana, Punjab, India.

Arora, R.P., M.S. Sachdev, Y.K. Sud, V.K. Luthra, and B.V. Subbiah. 1980. Fate of fertilizer nitrogen in a multiple cropping system. p. 3-32. In Soil nitrogen as fertilizer or pollutant. Int. Atomic Energy Agency, Vienna.

Aulakh, M.S. 1994. Integrated nitrogen management and leaching of nitrates to groundwater under cropping systems followed in tropical soils of India. p. 205-221. In Trans. 15th World Cong. Soil Sci. Vol. 5a. Acapulco, Mexico. Int. Soc. of Soil Sci.

Aulakh, M.S., and Bijay-Singh. 1997. Nitrogen losses and fertilizer N use efficiency in irrigated porous soils. Nutr. Cycl. Agroecosyst. 7:1-16.
Aulakh, M.S., J.W. Doran, and A.R. Mosier. 1992. Soil denitrification-Significance, measurement, and effects of management. Adv. Soil Sci. 18:1-57.

Aulakh, M.S., J.W. Doran, D.T. Walters, A.R. Mosier, and D.D. Francis. 1991. Crop residue type and placement effects on denitrification and mineralization. Soil Sci. Soc. Am. J. 55:1020-1025.

Aulakh, M.S., Kuldip-Singh, Bijay-Singh, and J.W. Doran. 1996. Kinetics of nitrification under upland and flooded soils of varying texture. Commun. Soil Sci. Plant Anal. 27: 2079-2089.

Aulakh, M.S., and N.S. Pasricha. 1997a. Fertilizer nitrogen management and environment pollution-Indian scenario. p. 296-313. In J.S. Kanwar and J.C. Katyal (ed.) Plant nutrient needs, supply, efficiency and policy issues: 2000-2025. Natl. Acad. of Agric. Sci. New Delhi.

Aulakh, M.S., and N.S. Pasricha. 1997b. Effect of green manuring and fertilizer $\mathrm{N}$ application on enhancing crop productivity in mustard-rice rotation in semiarid subtropical regions. Eur. J. Agron. 8:51-58.

Bartolome, V.I., R.M. Casumpang, M.A.H. Ynalvez, A.B. Olea, and C.G. McLaren. 1999. IRRISTAT for Windows-Statistical software for agricultural research. Biometrics, IRRI, Los Baños, Philippines.

Bajwa, M.S., Bijay-Singh, and Parminder-Singh. 1993. Nitrate pollution of groundwater under different systems of land management in the Punjab. p. 223-230. In First agricultural science congress-1992. Natl. Acad. of Agric. Sci., New Delhi.

Bijay-Singh, and G.S. Sekhon. 1977. Some measures of reducing leaching loss of nitrates beyond potential rooting zone. III. Proper crop rotation. Plant Soil 47:585-591.

Bijay-Singh, and Yadvinder-Singh. 1997. Green manuring and biological $\mathrm{N}$ fixation: North Indian perspective. p. 29-44. In J.S. Kanwar and J.C. Katyal (ed.) Plant nutrient needs, supply, efficiency and policy issues: 2000-2025. Natl. Acad. of Agric. Sci., New Delhi.

Bijay-Singh, Yadvinder-Singh, and G.S. Sekhon. 1995. Fertilizer-N use efficiency and nitrate pollution of groundnut in developing countries. J. Contam. Hydrol. 20:167-184.

Bouldin, D.R., S.D. Klausner, and W.S. Reid. 1984. Use of N from manure. p. 221-245. In R.D. Hauck (ed.) Nitrogen in crop production. ASA, CSSA, and SSSA, Madison, WI.

Buresh, R.J., and S.K. De Datta. 1991. Nitrogen dynamics and management in rice-legume cropping systems. Adv. Agron. 45:1-59.

Gill, G.S. 1995. Package of practices for kharif (summer) and rabi (winter) crops. Directorate of Ext. Educ., Punjab Agricultural Univ., Ludhiana, Punjab, India.

Gomez, K.A., and A.A. Gomez. 1976. Statistical procedures for agricultural research. 2nd ed. John Wiley and Sons, New York.

IRRI. 1991. World rice statistics 1990. IRRI, Los Baños, Philippines.

Khera, T.S., M.S. Aulakh, and J.W. Doran. 1999. Significance of soil depth on nitrogen transformations in flooded and nonflooded systems under laboratory conditions. Nutr. Cycl. Agroecosyst. 54: 209-213.

Kuldip-Singh, M.S. Aulakh, Bijay-Singh, and J.W. Doran. 1996. Effect of soil $\mathrm{pH}$ on kinetics of nitrification in semiarid subtropical soils under upland and flooded conditions. J. Indian Soc. Soil Sci. 44:378-381.

Ladha, J.K., and D.P. Garrity 1994. Green manure production systems for Asian ricelands. IRRI, Los Baños, Philippines.

Ladha, J.K., D.K. Kundu, M.G. Angelo-Van Coppenolle, M.B. Peoples, V.R. Carangal, and P.J. Dart. 1996. Legume productivity and soil nitrogen dynamics in lowland rice-based cropping systems. Soil Sci. Soc. Am. J. 60:183-192.

Maskina, M.S., Bijay-Singh, Yadvinder-Singh, and O.P. Meelu. 1988. Fertilizer requirement of rice-wheat and maize-wheat rotations on coarse-textured soils amended with farmyard manure. Fert. Res. 17:153-164.

Morris, R.A., R.E. Furoc, and M.A. Dizon. 1989. Rice responses to a short-duration green manure. II. $\mathrm{N}$ recovery and utilization. Agron. J. 78:413-416.

Mulvaney, R.L. 1996. Nitrogen-inorganic forms. p. 1123-1184. In D.L. Sparks (ed.) Methods of soil analysis. Part 3. SSSA Book Ser. 5. SSSA and ASA, Madison, WI.

Olson, R.J., R.E. Hensler, O.J. Attoe, S.A. Witzwl, and L.A. Peterson. 1970. Fertilizer nitrogen and crop rotation in relation to movement of nitrate nitrogen through soil profiles. Soil Sci. Soc. Am. Proc. $34: 448-452$ 
Sandhu, B.S., K.L. Khera, S.S. Prihar, and Baldev-Singh. 1980. Irrigation needs and yield of rice on a sandy-loam soil as affected by continuous and intermittent submergence. Indian J. Agric. Sci. 50:492-496.

Singh, I., Bijay-Singh, and H.S. Bal. 1987. Indiscriminate fertilizer use vis-a-vis groundwater pollution in central Punjab. Indian J. Agric. Econ. 42:404-409.

Singh, P. 1992. Nitrates in the soil profiles and ground waters under different systems of land use in the Punjab. M.Sc. thesis. Punjab Agric. Univ., Ludhiana, Punjab, India.

Spalding, R.F., and L.A. Kitchen. 1988. Nitrate in the intermediate vadose zone beneath irrigated cropland. Ground Water Monit. Rev. 8:89-95.

USEPA. 1985. Nitrate/nitrite health advisory (draft). USEPA, Office of Drinking Water, Washington, DC.
Walters, D.T., M.S. Aulakh, and J.W. Doran. 1992. Effects of soil aeration, legume residue and soil texture on transformations of macro and micronutrients in soils. Soil Sci. 153:100-107.

Westerman, R.L. 1990. Soil testing and plant analysis. 3rd ed. SSSA Book Ser. 3. SSSA, Madison, WI.

Yadvinder-Singh, Bijay-Singh, M.S. Maskina, and O.P. Meelu. 1988. Effect of organic manures, crop residues and green manure (Sesbania aculeata) on nitrogen and phosphorus transformation in a sandy loam soil at field capacity and under waterlogged conditions. Biol. Fertil. Soils 6:183-187.

Yadvinder-Singh, Bijay-Singh, M.S. Maskina, and O.P. Meelu. 1995. Response of wetland rice to nitrogen from cattle manure and urea in a rice-wheat rotation. Trop. Agric. (Trinidad) 72:91-96.

\title{
Using Growing Degree Days to Predict Nitrogen Availability from Livestock Manures
}

\author{
T. S. Griffin* and C. W. Honeycutt
}

\begin{abstract}
Predictive tools are needed to better match $\mathrm{N}$ release from manure with crop demand. Growing degree days (GDD) have been successfully used to predict $\mathrm{N}$ release from crop residues and other amendments. A 112-d incubation experiment was conducted at 10, 17, and $24^{\circ} \mathrm{C}$ to evaluate GDD $\left(0^{\circ} \mathrm{C}\right.$ base temperature $)$ predictions of $\mathrm{N}$ transformations from beef (Bos taurus), dairy, poultry (Gallus gallus), and swine (Sus scrofa) manure. Manure was incorporated at rates estimated to provide $150 \mathrm{~kg} \mathrm{~N} \mathrm{ha}^{-1}$ (or $75 \mathrm{mg} \mathrm{N} \mathrm{kg}^{-1}$ soil). Soil $\mathrm{NO}_{3}$ and $\mathrm{NH}_{4}$ concentrations were determined at weekly or biweekly intervals. The rate of $\mathrm{NO}_{3}$ accumulation increased with increasing temperature, and could be predicted across temperature regimes using GDD. This predictive ability could be generalized across dairy, poultry, and swine manures using an exponential equation, $\mathrm{NO}_{3}=$ $54.10[1-\exp (-0.006 G D D)]$, while $\mathrm{N}$ was immobilized by incorporation of beef manure. The disappearance of $\mathrm{NH}_{4}$ was a linear function of time and of GDD. A single predictive equation was sufficient for dairy, poultry, and swine manures, in the form $\mathrm{NH}_{4}$ (as percentage of input $)=0.703-0.0021 G D D\left(R^{2}=0.66\right)$, with soil $\mathrm{NH}_{4}$ reaching zero at $\approx 350$ GDD. These laboratory data indicate that GDD can be used for predicting $\mathrm{NO}_{3}$ accumulation and $\mathrm{NH}_{4}$ disappearance from a range of livestock manures. If successfully extended to the field, this predictive capability may allow for improved management of $\mathbf{N}$ from animal manures.
\end{abstract}

$\mathrm{I}$ MPROVED ability to predict the availability of $\mathrm{N}$ from organic sources, including livestock manures, plant residues, and industrial byproducts, would serve two complimentary purposes. First, at the farm level, supplemental fertilizer $\mathrm{N}$ application to crops could be restricted to those situations where a crop yield response is most likely, increasing productivity and avoiding unnecessary expense where a response is unlikely. Second, environmental loss of mineral $\mathrm{N}$ as $\mathrm{NO}_{3}$ could be re-

T.S. Griffin, Univ. of Maine, 495 College Ave., Orono ME 04473 1294; C.W. Honeycutt, USDA-ARS, New England Plant Soil and Water Lab, Univ. of Maine, Orono, ME 04469-5753. Joint Contribution from University of Maine and USDA-ARS. Maine Agric. and Forest Experiment Station Journal no. 2394. Partial funding from USDA-SARE, Project ANE94-20. Received 18 Oct. 1998. *Corresponding author (tgriffin@umext.maine.edu).

Published in Soil Sci. Soc. Am. J. 64:1876-1882 (2000). duced by both eliminating unneeded application and better matching mineral $\mathrm{N}$ supply with crop demand.

Season-long mineralization constants for the organic $\mathrm{N}$ component of manure are broadly based on the recalcitrance of the organic $\mathrm{N}$ fraction. Mineralization constants for composted manures are commonly 5 to $10 \%$ $\mathrm{yr}^{-1}$ (Hadas and Portnoy, 1994). Conversely, Bitzer and Sims (1988) found that an average of $66 \%$ of the organic $\mathrm{N}$ in poultry manures was mineralized in the first year. Cabrera et al. (1994) confirmed this rapid mineralization from poultry manures, estimating that 35 to $50 \%$ of organic $\mathrm{N}$ could be mineralized within $14 \mathrm{~d}$ of incorporation into soil. Estimated mineralization constants for dairy and beef manures usually fall between these extremes (e.g., 16-21\% by Klausner et al., 1994). These estimated mineralization constants are useful in calculating N-based application rates. However, they do not provide sufficient detail to make supplemental $\mathrm{N}$ application decisions during the growing season.

Estimating the amount of mineral $\mathrm{N}$ available from manure during the growing season is further complicated by the presence of both mineral $\mathrm{N}$ (usually $\mathrm{NH}_{4}$ ) and organic $\mathrm{N}$ fractions. Ammonium is subject both to rapid nitrification to $\mathrm{NO}_{3}$ and to volatile loss as $\mathrm{NH}_{3}$, while organic $\mathrm{N}$ requires an initial mineralization step to be utilized by plants. Because both nitrification and mineralization are microbially mediated in soil, they are influenced not only by substrate characteristics, but also by soil climate, including temperature, soil water status, and aeration.

In past research, thermal units or GDD have been used successfully to predict cumulative $\mathrm{N}$ mineralization through a growing season for carbonaceous wastes, biosolids, and plant residues of varying composition (Honeycutt et al., 1988, 1991; Honeycutt and Potaro, 1990), recognizing that the thermal unit relationship with mineralization is modified by soil water status (Doel et al., 1990). For livestock manures, a general relationship between $\mathrm{N}$ mineralization and temperature was demon-

Abbreviations: GDD, growing degree days; ICP, inductively coupled plasma emission spectroscopy; PAN, plant-available N. 